\title{
Justice For Animals ACCORDing to Plutarch
}

Damian Miszczyński ${ }^{1}$

ABSTRACT: This paper is an attempt to describe Plutarch's view on the idea of justice between animals and humans on the basis of a representative selection of passages from his works. Most of the analyzed passages are from De sollertia animalium and De esu carnium. The criterion of selection was lexical and contextual, so passages containing words semantically related to the Greek terms for justice or law were particularly taken into account, as well as passages simply referring to the subject of justice for animals. The conclusion is that Plutarch believed that justice between humans and animals is possible and should be applied. However, conscious of how difficult this postulate is to achieve, he was content with urging people to limit the consumption of meat.

KEYWORDS: Vegetarianism in Antiquity; Animal justice; Human-animal relations; Plutarch.

\section{Introduction}

Plutarch is one of the best known of ancient authors who raised the question of just treatment of animals. This question is linked primarily with the abstinence from killing and eating animals, on the basis that right to life should be respected by humans. Plutarch himself probably was a vegetarian for at least some part of his life before he became a priest of Delphi, and without any doubt he may be called a great defender of animals - a stance he expressed often enough in his works. In his writings, he usually criticizes mistreatment of animals or eating of animal flesh, as in Cato Maior, De tuenda sanitate pracepta, Quaestiones convivales. Furthermore, three of his treatises are entirely devoted to animals: De sollertia animalium, Bruta animalia ratione uti, and De esu carnium. He was not the only ancient writer concerned with the idea of interspecies justice, regardless of whether it is possible or not. Among them, there were also Pythagoras (sixth century BC), Empedocles (fifth century BC), Aristotle (384-322 BC), Theophrastus (370-287 BC), Epicurus (341-270 BC), Chrysippus (280-206 BC), Posidonius (135-51 BC) and Porphyry (234-305 AD).² Moreover, references to this discussion - and that was indeed a discussion that extended

\footnotetext{
${ }^{1}$ Jagiellonian University. This paper is financed by the budgetary funds for science in 2014-2018 as a research project under the program named Diamond Grant by the Ministry of Science and Higher Education of Poland. E-mail: damian.miszczynski@doctoral.uj.edu.pl.

2 A representative selection of ancient texts on animals can be found in Newmyer (2011).
} 
over a long time - can also be found in Democritus (460-357 BC), Cicero (106-43 BC), Ovid (43 BC-17/18 AD) and Sextus Empiricus (c. 160-c. 210 AD). This brief list of authors, who refer to the notion of justice in contexts of human-animal relations, shows that this question has been raised in every century since the very beginning of ancient philosophy. In general, there can be distinguished two opposite views on justice toward animals. One states that there cannot be any bounds of justice between humans and animals. This view is presented most of all by Aristotle (Politica, 1253a9-18, 1332b3-8; Ethica Nicomachea, 1161a3o1161b2) and the Peripatetics, Chrysippus (SVF, 2.821) and the Stoics, and Epicurus and his followers (Diogenes Laertios, Vitae philosophorum, X, 150; Porphyry, De Abstinentia, 1.7-12). The basis for that opinion is, according to them, the irrationality of animals which exist to be used by humans with no moral objections. On the other hand, the attitude advocated mainly by Plutarch (explained below) and Porphyry (De Abstinentia 3.9-19) argues that humans should treat animals according to principles of justice, because they are sensible and rational creatures, although to a much lesser degree than humans. ${ }^{3}$ The consequence of that opinion is the necessity to respect animal right to life and not to kill them, unless in self-defence. Moreover, humans are allowed to use animals for work, but only if providing them with care and safety in exchange for their help.

Plutarch's role in that debate might have been particularly important. Lecky (1890, p. 248; see also Tsekourakis, 1987, p. 380) noted that Plutach was probably the first author to defend animals independently of the Pythagorean doctrine of the transmigration of souls. ${ }^{4}$ Indeed, analyses of the earliest written sources (Plato, Leges 782C; Euripides, Hippolytus 952-954, Alcestis 967-969; Empedocles B117, B128; Herodotus, Historiae, II, 123) lead to the conclusion that the main motives for the vegetarianism, and in consequence for the postulate of not killing animals, are definitely more of religious than of ethical nature (Miszczyński, 2015, p. 3-23). The motivation for saving human souls which reincarnated in animal bodies after death is still anthropocentric - because it is

\footnotetext{
3 However, Edwards $(2014,2016)$ argues that Porphyry did not actually believe that all animals are rational and claims that the supposed rationality of animals is not the base for Porphyry's theory of justice toward animals.

4 However, Balaudé (1997) argued that Empedocles' ethical system was based on his own innovative theory of "parenté du vivant" - the kinship of the living, which resulted in his vegetarianism.
} 
all about the human soul and not the animal's life -, whereas Plutarch is the first of the preserved authors who supports vegetarianism and care for animals with a wide range of arguments other than religion.

Haussleiter, the author of the first monograph on ancient vegetarianism as rationalen motiven in Plutarch, points out, for instance, the purity of mind and health of the body as the supposed consequences of not eating animal flesh. But as the most important motive for this he recognizes the moral postulate of justice toward animals, resulting from his acknowledgment of them as intelligent creatures (Haussleiter, 1935, p. 228). Haussleiter saw the source of Plutarch's vegetarianism in the Pythagorean thought, which was getting more popular during the first century AD. I agree with his interpretation, but Plutarch's own contribution to the debate should not be neglected. Plutarch could have learned about vegetarianism through both the Pythagorean thought (especially considering the fact that he lived in the period of Neopythagorean revival) and the religious tradition of the Orphics (De esu carn. I, 7.996B), 5 but he developed his own ideas on the matter, going beyond the polemics with the Stoics on the rationality of animals. Plutarch states clearly that animals are rational and sensible creatures, which, accordingly, should have the right to life, to which they are entitled by birth (De esu carn. I, 4.994E) Humans should respect that right, with killing of animals being allowed only in case of necessity.

Plutarch exposes his ideas on the treatment of animals in two treatises from Moralia, namely De sollertia animalium and in De esu carnium. The former is known under the English title Whether Land or Sea Animals Are Cleverer or simply On the Intelligence of Animals. It is a dialogue composed of two main different parts and a short ending. In chapters 1-8 Autobulus, Plutarch's father and his mouthpiece in this dialogue (Hubert, 1979, p. 102), speaks with Soclarus, a friend of the household who presents views of the Stoics and the Peripatetics. The subject of their conversation is, first of all, the question of rationality of animals and, as a result of that, the idea of justice. The second part of the dialogue, chapters 9-36, contains a rhetorical competition between Aristotimus and Phaedimus in which the former argues for the superiority of the intelligence of land animals, and the latter for the superiority of sea animals. The short chapter

5 References to Plutarch's works follow the numeration of chapters and/or the Stephanus pagination. 
37 concludes that neither of them wins the contest, but indicates that both, being instructed by each other, can stand in defense of the rationality of all animals in general. This conclusion converges with the introductory part of the dialogue which suggests that justice should be applied to all animals. ${ }^{6}$ The latter work consists of two separate speeches on the same topic, probably given day after day - as the text itself points out: "Reason urges us with fresh ideas and fresh zeal to attack again our yesterday's discourse on the eating of flesh." (II, 1.996D),- 7 known under a common title On the Eating of Flesh. It is in fact a vegetarian manifesto in which Plutarch calls for abstinence from eating meat providing many arguments. Of course, there also appears terminology linked with law and justice, especially when Plutarch expresses his criticism of Stoic concepts, which he tends to do at almost every opportunity. Unfortunately, this work has not survived in its entirety. The last passages allow us to suppose that the unpreserved rest of the work was directly dedicated to justice for animals and to the polemics with the Stoics on that matter. But despite that, the content of the available text is sufficient to define Plutarch's attitude on the matter.

The purpose of this paper is to discuss Plutarch's view on justice for animals based on selected passages from De sollertia animalium and De esu carnium. The criterion of my selection was lexical and contextual, so I chose

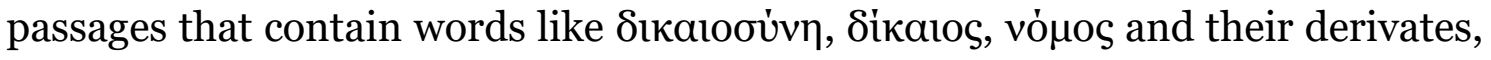
as well as passages which clearly approach the question of justice for animals, even if they do not present these specific terms.

Analysis of selected passages from De sollertia animalium ${ }^{8}$

Autobulus and Soclarus start a conversation about the rationality of animals referring to a speech in praise of hunting which was given on the day before (ch. 1-8).9 First, Soclarus presents the attitude of the Stoics and Peripatetics, who deny reason to the animals, consequently also denying them access to justice:

\footnotetext{
${ }^{6}$ That is how Schuster defined the aim of that dialogue (as cited in Cherniss \& Helmbold, 1957, p. 312 , fn. $b$ ).

7 Plutarch similarly refers to his speech from the previous day at the beginning of Fortuna Alexandri part II.

${ }^{8}$ All cited passages are from Helmbold's translation, unless stated otherwise.

9 On the speech in praise of hunting, see Hubert (1979).
} 
For the Stoics and Peripatetics strenuously agree on the other side, to the effect that justice could not then come into existence, but would remain completely without form or substance, if all the beasts partake of reason. For either we are necessarily unjust if we do not spare them; or, if we do not take them for food, life becomes impracticable or impossible; in a sense we shall be living the life of beasts once we give up the use of beasts. I omit the numberless hosts of Nomads and Troglodytes who know no other food but flesh. As for us who believe our lives to be civilized and humane, it is hard to say what pursuit on land or sea, what aerial art, what refinement of living, is left to us if we are to learn to deal innocently and considerately with all creatures, as we are bound to if they possess reason and are of one stock with us. So we have no help or cure for this dilemma which either deprives us of life itself or of justice, unless we do preserve that ancient limitation and law by which, according to Hesiod, he who distinguished the natural kinds and gave each class its special domain:

To fish and beasts and winged birds allowed

Licence to eat each other, for no right

Exists among them; right, he gave to men

for dealing with each other. Those who know nothing of right action toward us can receive no wrong from us either. For those who have rejected this argument have left no path, either broad or narrow, by which any may slip in (6.963F-964C). ${ }^{10}$

According to this view, to acknowledge animals as rational creatures would either lead to a complete denial of the concept of justice or to making people's life impossible. In the first case, humans impose on themselves a necessity of harming animals if they do not spare them ( $\dot{\alpha} \delta 1 \kappa \varepsilon \tilde{\imath} v \dot{\alpha} v \alpha \gamma \kappa \alpha \tilde{i} \sigma v \dot{\eta} \mu \tilde{v} v$ $\dot{\alpha} \varphi \varepsilon \imath \delta$ oṽ $\sigma v \alpha \hat{\tau} \tilde{\omega} v)$, or, according to the etymology of the used word to be precise, a necessity of committing injustice. In the word $\hat{\alpha} \delta \delta_{1 \kappa \varepsilon i v}$, there is a negating alpha privativum and a verb negated by it, which comes from the noun $\delta i \kappa \eta$, which means "justice". In the second case, if people completely stop using animals,

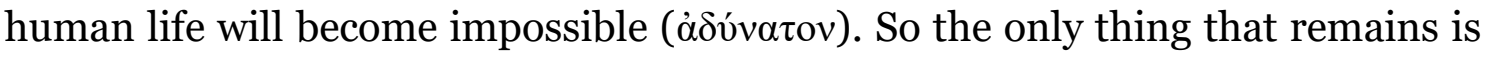
to preserve the divine order established by Zeus as it is presented in the passage from Hesiod's Opera et dies quoted by Soclarus in the dialogue. This order was based on the idea that only humans partake of justice whereas animals do not, and that is why they kill and eat each other. If they are not capable of acting justly

${ }^{10}$ Cf. Hes. Opera et dies, 277-279. 
toward us ( recognized as unjust.

At the very beginning of the discussion on the justice for animals, there arises a question about the concept of justice itself and its presence among animals (see Newmyer, 1997). It is consistent with the assumption that the relation of justice should be mutual, so both sides should understand the concept. That question also appears in other passages of Plutarch's work. In De soll. an. chapters 4-5.962A-963A, Plutarch seems to admit that animals have a sense of

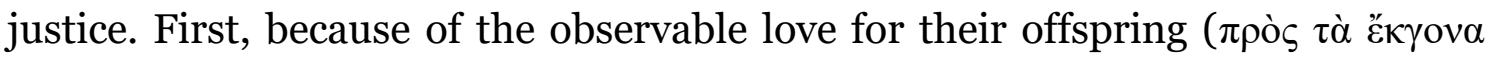
$\varphi \imath \lambda o \sigma \tau o p \gamma i \alpha v)$, which according to the Stoics is considered the foundation ( $\dot{\alpha} \rho \chi \eta$ ) of justice, at least in the case of humans. Second, because he admits that humans

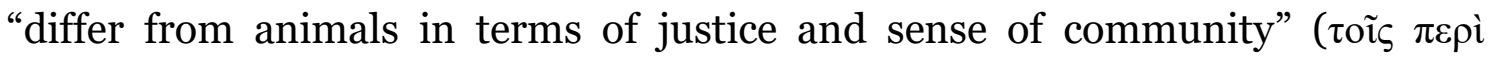

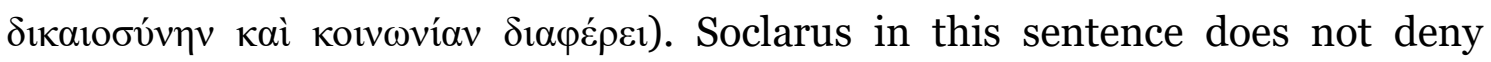
animals a sense of justice and community. He only points out that there is a big difference between humans and animals in those terms. The same question comes up in behavioral descriptions of various animals, adduced in the discussion between Aristotimus and Phaedimus. ${ }^{11}$ Plutarch also seems to attribute a sense of justice to animals in De esu carn., I, 4.994E, where we learn about "forensic

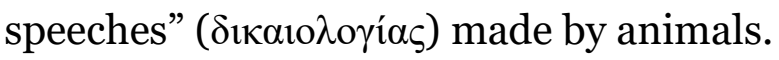

On the other hand, Helmbold (1957, p. 349, fn. $b$ ) supposed that later in life Plutarch changed his position on this matter based on an argument presented by Soclarus, namely that humans are not able to commit injustice to creatures which cannot act justly toward humans. Helmbold also refers to a passage from Cato Maior (5.339A): "Law and justice we naturally apply to men alone" (vó $\mu \omega$

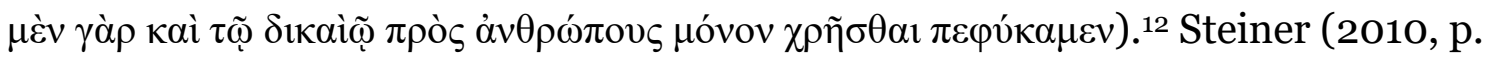
81) follows Helmbold's interpretation that this passage demonstrates a shift in Plutarch's thinking. But this sentence should be read as a simple statement of fact, not as a norm postulated by Plutarch. In that chapter he criticizes Cato and his "mean nature" for mistreating slaves, whom he used for hard work until they got old and then drove them off and sold them, recognizing no tie between man and man but that of necessity, despite the fact that law and justice should be in

${ }^{11}$ I omit them those descriptions, because examples given in that discussion are completely unbelievable and nowadays cannot be treated as serious arguments or proofs.

${ }^{12}$ For passages from Cato Maior, I use Bernadotte Perrin's translation. 


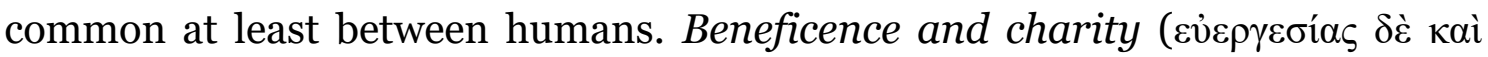

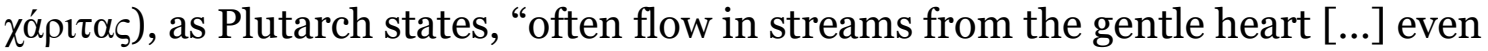
to dumb beasts" (Cat. Mai., 5.2). In the sequence, he gives as an example of a kind man a person who takes good care of his horses and dogs even in their old age. Sorabji (1995, p. 118) calls it "the compensating manoeuvre" used by Plutarch in order to make the denial of justice (in a narrow sense) "more palatable", but the aim of that manoueuvre is, at least, to promote benevolence toward animals. Sorabji (1995, p. 125) also points out that he has not found this argument - "that benevolence is owed to animals, even if justice is not" - anywhere else. It looks like Plutarch is trying to convince people to behave justly toward animals, simultaneously avoiding to use the proper names, which may be too difficult to accept for the audience. In the end, I claim that Plutarch's message in chapter 5 of Cat. Mai. is far from making a statement that humans are not able to commit injustice to animals, especially when he states there clearly that:

We should not treat living creatures like shoes or pots and pans, casting them aside when they are bruised and worn out with service, but, if for no other reason, for the sake of practice in kindness to our fellow men, we should accustom ourselves to mildness and gentleness in our dealings with other creatures (Cat. Mai., 5.5).

But probably some scholars' prejudices against certain ideas of Plutarch about animals may lead to depreciation and undermining of these ideas (Newmyer, 1992, p. 41-42). This applies, for example, to Cherniss and Helmbold (1957) or Ziegler (1964). However, in De amore prolis 3.495B-C, there is also a passage that says: "so on irrational animals she [Nature - D.M.] has bestowed a love of offspring, though imperfect and insufficient as regards the sense of justice

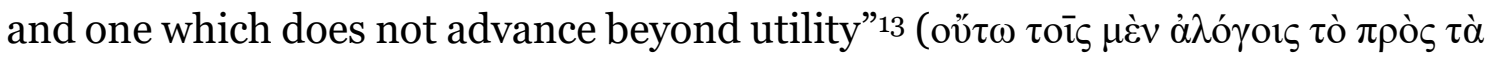

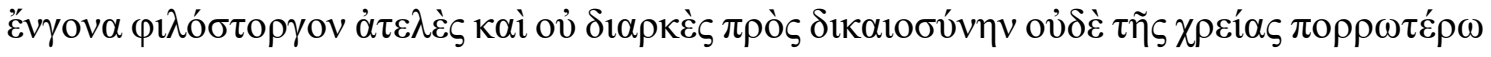
$\pi \rho о \varepsilon \rho \chi 0$ $\mu \varepsilon v o v)$. Then, animals are contrasted with humans who are rational and

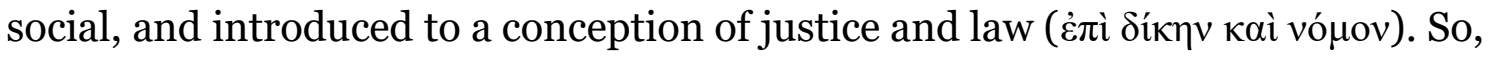
there is that clear distinction and explanation of why justice belongs to humans, but not to animals. Note, however, that De amor. prol. raises many problems among scholars because of its current state of preservation, uncertain dating, and

${ }^{13}$ For De amore prolis, I use Helmbold's translation. 
inconsistencies with other Plutarch's works (Helmbold, 1939, p. 328-329; Roskam, 2011). Besides, a position which denies animals the ability to understand what justice is does not exclude a possibility of having them protected by the same justice. This point is relevant because Plutarch's argument for the extension of justice for animals is not based exclusively on demonstrating their rationality. Steiner (2010, p. 80) evokes the philosophical concept of "moral patients", i.e., "beings to whom we have moral obligations even though they cannot take on reciprocal obligations toward us", which would apply to animals in Plutarch's claims. ${ }^{14}$ Newmyer (2006, p. 119, fn. 109) sums up the discussion about this passage, leaning towards Becchi's (1993, p. 60-70, 2000, p. 2015-215) interpretation that even in De amor. prol. Plutarch accords some degree of reason to animals, but his intention was rather to chastise human frailty than to downplay animal intellect. In the context of this discussions it is also worth to remind Rawls' (1999, p. 448) stance that we are not required to give strict justice to creatures lacking a sense of justice, but it does not follow that we are not required - in case of animals - to treat them with compassion and humanity because of their sentience. Similarly says Newmyer (2006, p. 65) about Plutarch's theory of justice, that in his vision animals' capacity to experience distress and pain has moral relevance for human action. Behind this fact, as Newmyer argues, lies the argument of oikelótns, i.e., relationship of appropriation or affinity with beings which share the same interests, like, for example, an interest in staying alive. ${ }^{15}$

Plutarch is referred by his father, Autobulus, in chapter seven of De soll. an. He declares explicitly that he will be presenting a way to justice suggested by his son, which is, as he says, "neither so treacherous nor so precipitous, nor is it a route lined with the wreckage of obvious truths" (7.964D). Moreover, it was elaborated "under the guidance of Plato". 16 That way is described as follows (7.964E-F):

\footnotetext{
14 To illustrate it, a similar situation applies to men when children cannot understand what is justice, and yet they are subjects protected by it.

${ }_{15}$ This concept is also known as oikei $\omega \sigma ı$. Cf. Sorabji (1995, p. 122-133); Brink (1956).

${ }^{16}$ This "guidance" probably refers to a passage in Plato (Leges 782C) where there is a mention on the so-called "Orphic life", which included refraining from animal sacrifice and meat eating.
} 
For there is an alternative, an inoffensive formula which does not, on the one hand, deprive beasts of reason, yet does, on the other, preserve the justice of those who make fit use of them. When the wise men of old had introduced this, gluttony joined luxury to cancel and annul it; Pythagoras, however, reintroduced it, teaching us how to profit without injustice. There is no injustice, surely, in punishing and slaying animals that are anti-social and merely injurious, while taming those that are gentle and friendly to man and making them our helpers in the tasks for which they are severally fitted by nature.

This alternative approach does not deny animals rationality (reason, $\lambda$ óyov), and simultaneously allows to make use of them while maintaining justice. Introduced by the wise men of old, who are not mentioned by name, this approach was abandoned because of gluttony and luxury until came Pythagoras with his teachings. These wise men should not be understood as particular ancient sages, especially since, as we know, Pythagoras himself is one of the earliest Greek philosophers. Rather, Plutarch has in mind some unspecified ancient wise men, most probably men of the mythic Golden Race described by Hesiod in his Opera et dies (109-120). According to Hesiod, people then received abundance of food from the earth and without work. ${ }^{17}$ Besides, Plutarch quotes in De esu carn. Aratus' Phaenomena, and that quotation refers to the same myth, which shows the Race of Bronze as them, who "were the first to forge the sword of the highwayman, and the first to eat of the flesh of the ploughing-ox" (II, 4.998A = Phaen., $131 \mathrm{ff}$.). ${ }^{18}$ In De esu carn. Plutarch hypothesizes that most of ancient people did not kill animals and did not eat flesh, but at some stage in history they started to do that and fell in love with it, thereby increasing their insensitivity. A similar thought also appears in De soll. an. (see De esu carn. I, 12.993A-994A, II, 4.998A-B; De soll. an. 2.959D-F). Furthermore, the sentence cited above is from a passage of Phaen. which describes the constellation of Virgo. According to the myth, this constellation was the personification of Justice ( $\Delta \mathrm{i} \kappa \eta$ ) living on earth among people until came the Race of Bronze (Phaen., 96-136). With regard to Pythagoras and the Pythagoreans, there are a lot of studies on their supposed vegetarianism, which is a subject of a wide scholarly discussion, but

${ }_{17}$ On the succession myth of races, see West (1997, p. 417-426).

${ }_{18}$ Mair's translation. 
Plutarch was convinced that they practised a vegetarian diet and he refers to that many times in his works. ${ }^{19}$

Let us now examine this new way of thinking postulated by Plutarch. According to him, injurious animals may be killed, whereas gentle and friendly animals can be made co-workers of humans in compliance with their nature. Plutarch even invokes verses of a poetic authority, Aeschylus, which tell about the titan Prometheus giving draught animals to humans in order to help them in arduous work. But there still remains the question about eating animals, and Plutarch does not give a consent to that in De soll. an. (7.965A):

For living is not abolished nor life terminated when a man has no more platters of fish or pate de foie gras or mincemeat of beef or kids' flesh for his banquets - or when he no longer, idling in the theatre or hunting for sport, compels some beasts against their will to stand their ground and fight, while he destroys others which have not the instinct to fight back even in their own defence.

According to him, being deprived of such delicacies will not "terminate" a human's life, as well as giving up forcing animals to fight each other in theatres or killing defenceless animals on hunting. But Plutarch (7.964E-F) would probably allow to hunt predators, animals injurious and capable of confronting humans if in self-defence. He does not specify what he means by the words "living is not abolished nor life terminated", but the same thought can be found, more developed, at the very beginning of the De esu carn. (I, 2.993D-994A). In this treatise, he talks about the abundance of food of plant origin, which is sufficient enough to feed all men without necessity to kill animals for meat. Moreover, Plutarch criticizes hunting, and even fishing, because by these activities humans enjoy death and suffering of animals. All of Autobulus' investigation in De soll. an., where Plutarch's position is presented, ends with the following summarizing sentence: "The fact is that it is not those who make use of animals who do them wrong, but those who use them harmfully and heedlessly and in cruel ways" (7.965B). So, it is not the mere exploitation of animals that is doing injustice

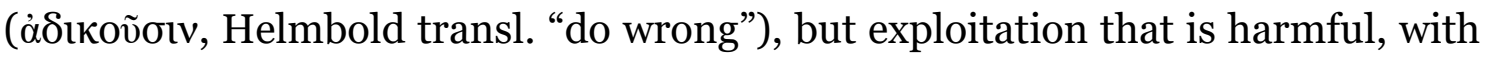

19 On the Pythagorean vegetarianism see, for example, Tsekourakis (1987, p. 370-379); Cornelli (2013, p. 70-71); Cornelli et al. (2013, p. 50, 120-122). 
contempt and cruelty. But it is to be noted that Plutarch often appeals simply to human emotions, and that feature of him will be especially visible in De esu carn. Apparently, he believes in simple human recognition of what is cruel and harmful use of animals. Newmyer (1992, p. 47) noticed that Plutarch in that respect is quite unique among other ancient defenders of animals.

Later in the text of De soll. an., precisely in Aristotimus' speech for the greater intelligence of land animals, the issue of animal justice is raised again, but this time it seems in some way restricted:

Therefore those who deny that there is any kind of justice owed to animals by us must be conceded to be right so far as marine and deep-sea creatures are concerned; for these are completely lacking in amiability, apathetic, and devoid of all sweetness of disposition. [...] But a man who would use such speech in regard to land animals is himself cruel and brutal (14.970B-C).

This refers to the Stoics, who must be conceded to be right in their opinion on justice for animals, but not unreservedly. They might be right, but

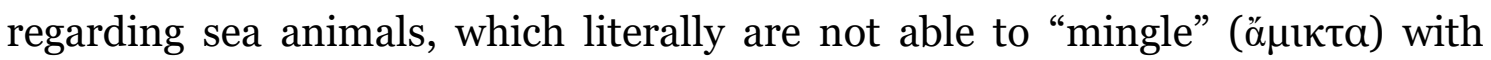
humans. In comparison with many land animals, especially domesticated ones that live with humans, sea creatures neither arouse affection in nor show it to humans. However, there are exceptions, like dolphins which are mentioned a few times in De soll. an. The legend about the poet Arion, rescued from drowning by dolphins, was widely known in Antiquity, and there were also other cases of dolphin friendliness towards men (36.984A-985C). The passage denying justice to sea animals includes examples of intimate relations between humans and certain land animals, which is aimed against sea animals. But Phaedimus, speaker in the second part of the dialogue, will also refer to similar examples of personal relations of humans with sea animals. He starts their apology with the statement that most part of the life of sea creatures remains hidden from men's view because of living in a quasi-other world (23.975D-976A), but it does not mean that they lack rationality or social instinct. Only representatives of marine occupations see a little more of this water world, so they can testify to the veracity of the examples to which Phaedimus referred. On the other hand, land animals are not only easier to observe by everyone, but also, according to Phaedimus' 
speech, they "have to some extent been imbued with human manners" (23.975EF) because of their cohabitation and close relations with humans. Plutarch metaphorically mentions the taming and domesticating process of animals which live with men.

To summarize the message of De soll. an., it must be noted that Plutarch, in fact, does not deny justice to sea animals. A deeper look at the examples of animals provided by Aristotimus and Phaedimus makes it clear that this distinction between land and sea animals is artificial and works only as an excuse to have two opposing sides in the dialogue. ${ }^{20}$ The two speakers participate in a competition, but in the end there is no winner. The conclusion of all the discussion is that both opponents now can "together put up a good fight against those who would deprive animals of reason and understanding" (37.985C). It refers to the Stoics, with whom Plutarch was polemizing, especially with regard to animals and their treatment. Some critics expressed suspicions that the ending of De soll. an. is too brief and vague to be of Plutarch's authorship, but Helmbold (1957, p. 312, 479, fn. c) saw it as a possible indication that "the whole debate is in reality a single argument to prove the thesis that animals do have some degree of rationality". I would even state that it is implicitly an argument in favour of extending justice to animals, if rationality is considered a criterion of justice. However, the following analysis of De esu carn. will show that the rationality of animals does not have to be the most important reason for extending justice to them.

Analysis of selected passages from De esu carnium

The starting point of the discourse is a question about the reason of Pythagoras' vegetarianism, which Plutarch at once inverts, asking about the origins of meat eating and the reasons why humans did begin to eat meat. According to him, it is consuming dead animals which needs an explanation, rather than rejecting such a diet. In chapter two, Plutarch attempts to answer his own question by invoking a hypothetic speech of one of the first men. By doing this, Plutarch aims to explain his contemporaries how animals begun to be killed

\footnotetext{
${ }^{20}$ Although the text explicitly says "sea animals", it also mentions in fact freshwater animals, and
} even crocodiles or certain birds that live close to water. 
and eaten: it was a necessity due to the prevailing of famine. This explanation is followed by accusations and reproaches because the speaker notices contemporary abundance and welfare, thus expressing his astonishment about the fact that men still practice killing and eating animals:

But you who live now, what madness, what frenzy drives you to the pollution of shedding blood, you who have such a superfluity of necessities? [...] You call serpents and panthers and lions savage, but you yourselves, by your own foul slaughters, leave them no room to outdo you in cruelty (I, 2.994A-B).

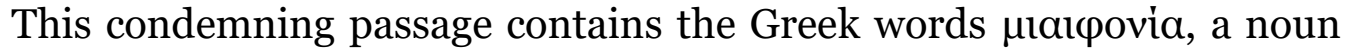

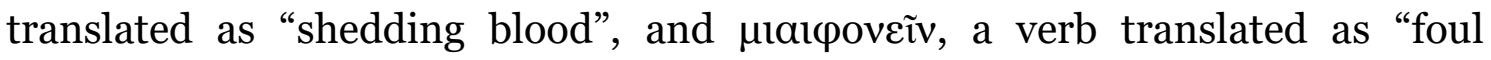
slaughters", which are words neither simply for "killing" nor typically used with regard to the killing of animals - these usually come from the ritual context and mean offering a sacrifice. They consist of two lexemes: $\mu$ raiv $\omega$, a verb for "stain", "sully"; "taint", "defile", and poví, a noun for "carnage"; "blood shed by slaying”. As such, they constitute a negative term for murdering, staining oneself with murder, and they are usually applied to humans. The fact that Plutarch calls killing animals by the word meaning one of the worst crimes among humans indicates, in my opinion, that he considered it an act against justice, which is supposed to be normatively applied also to animals.

In chapter four, the philosopher speaks again in his own name, wailing that nothing can dissuade humans from killing animals, even their cries and squeaks, when they are led to the slaughter. Once more he uses a rhetorical figure and quotes a hypothetic speech, although it is only one sentence. But what is strikingly unique is that this sentence is an attempt to translate these animal moans and squeaks into human language:

No, for the sake of a little flesh we deprive them of sun, of light, of the duration of life to which they are entitled by birth and being. Then we go on to assume that when they utter cries and squeaks their speech is inarticulate, that they do not, begging for mercy, entreating, seeking justice, each one of them say, "I do not ask to be spared in ease of necessity; only spare me your arrogance! Kill me to eat, but not to please your palate!” (I, 4.994E) 
Helmbold simplified the original text in his translation, so it requires a closer look at the Greek words to get a better understanding. He translated $\psi v \times \tilde{y} \varsigma$ as "them", while its precise meanings are "breath", "spirit", "life", "soul", and it is grammatically singular genitive. So, that particular life or soul of an animal is

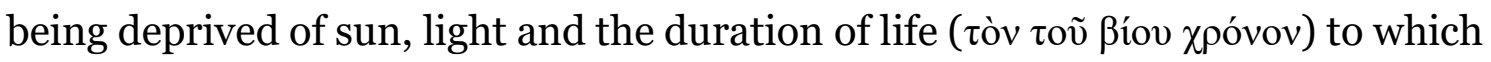
it was born. The key element in the sentence is the Greek preposition غ̇лi with dative, which can express cause, reason or purpose. According to this idea, an animal has the basic right to live its own life just for having been born and for living - Dierauer (1977, p. 274) described this stance as the "polemical antithesis to Stoic anthropocentrism". Violation of this right is therefore treated as violation of justice itself, and as a crime. In the second part of the passage cited above, Plutarch uses metaphors to explain the message hidden behind the cries and squeaks of animals led to slaughter. Again, Helmbold's translation is not precise enough. Plutarch says that these animals' voices are in fact "supplications and

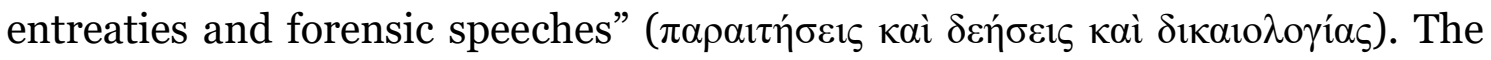
first two terms are completely understandable, but the third needs a comment.

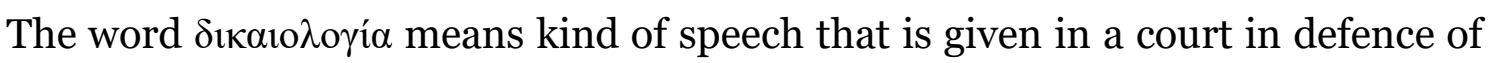
somebody. Applying such a word to animals may be ascribing indirectly to them not only certain conciousness of justice, but also subjectivity. Newmyer (2006, p. 62) points out that "the true horror of the scene emerges only if we realize that, in this case, the animal has a sense of justice superior to that of humans who exploit it" and that Plutarch appeals here to human emotion. But in regard to the content of this hypothetic speech, it can be confusing, because an animal actually agrees to be killed and eaten. So, does it mean that Plutarch allowed killing animals for food? In De soll. an. he allowed killing animals, but as a defence or a necessity (7.964E-F). In this case, he also recognizes a ground for excluding, so to speak, criminal responsibility with the justifying of the act, again a matter of necessity, not of pleasure. If a man is not able to feed on food that are not from animals, such as the first men from the passage of De esu carn. I, 2.993D-994B or Nomads and Troglodytes from the passage of De soll. an. 6.964A, and if eating animal flesh is the only condition for survival, then killing and feeding on animals are justified.

Plutarch goes even further. His approach is characterized more by realism than strict adherence to the principles of vegetarianism. At the beginning 
of the second speech of De esu carn., he seems to give up his principles by allowing the eating of meat, but he also asks for restraint, self-reflection and humane treatment of animals:

Yet if, for heaven's sake, it is really impossible for us to be free from error because we are on such terms of familiarity with it, let us at least be ashamed of our ill doing and resort to it only in reason. We shall eat flesh, but from hunger, not as a luxury. We shall kill an animal, but in pity and sorrow, not degrading or torturing it (II, 1.996E-F).

This actually repeats and clarifies the message from the passage quoted above (I, 4.994E). A detail to be noticed is that the translated phrase "free from

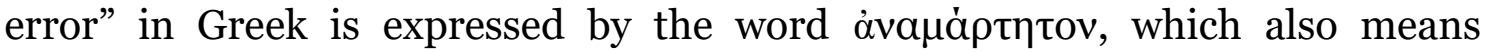
"blameless", "guiltless". A similar argument, though with certain reservations, can be found in De tuenda sanitate praecepta, where Plutarch advises against eating meat, most of all for health reasons, but he still allows it. There he says:

But since custom has become a sort of unnatural second nature, our use of meat should not be for the satisfaction of appetite, as is the case with wolves or lions; but while we may put it in as a sort of prop and support of our diet, we should use other foods and relishes which for the body are more in accord with nature and less dulling to the reasoning faculty, which, as it were, is kindled from plain and light substances. ${ }^{21}$ (Plut. De tuenda sanit. praec. $18.132 \mathrm{~A}$ )

Helmbold (1957, p. 537), who seems skeptical about Plutarch's ideas, considered this passage an excuse for flesh-eating. The philosopher would have changed or softened his views over time because De tuenda sanit. praec. is his later work, with $81 \mathrm{AD}$ as terminus post quem, as there is a reference to the death of Emperor Titus (Plut. De tuenda sanit. praec. 5.123D), whereas De esu carn. is one of Plutarch's early works (Krauss, 1912, p. 80-83). However, in the passage from De esu carn. cited above (II, 1.996E-F), there is permission for eating meat, so one can hardly argue serious changes in Plutarch's thinking. He is consistent, as he strongly advises against eating meat and killing animals by presenting a series of arguments from various fields, but at the same time he realises how

\footnotetext{
${ }^{21}$ Babbitt's translation.
} 
difficult it can be to accomplish his postulates (II, 1.996D-E). Because of that, he is content with advising his audience to reduce the consumption of meat, and with arousing compassion and remorse in order to at least prevent human cruelty to animals.

There was indeed cruelty to animals in Antiquity, especially in the age of the Roman Empire, and nobody doubts it. Plutarch himself in De esu carn. II, 1.997A mentions brutal examples of treatment towards certain farm animals, bred for human consumption. But he also mentions quite a few unexpected cases of a human being punished for animal abuse:

Two days ago in a discussion I quoted the remark of Xenocrates, ${ }^{22}$ that the Athenians punished the man who had flayed a ram while it was still alive; yet, as I think, he who tortures a living creature is no worse than he who slaughters it outright. But it seems that we are more observant of acts contrary to convention than of those that are contrary to nature (I, 7.996A-B).

Plutarch does not present any details of that incident because he was probably talking about it in a conversation he had two days before, but he still refers to the case just to provide an additional commentary. And this is actually a critical one: the punishment was imposed because someone acted contrarily to convention and tortured a living animal, but in Plutarch's opinion it should not be considered worse than just taking its life away. Killing, which he calls an act contrary to nature, is commonly accepted by people, while flaying an animal alive involves punishment. Plutarch cries out against human inconsistency, namely that men are more concerned about acts of lesser rank. Regardless of the specific circumstances of that incident, it is clear from Plutarch's statement that he is strongly against killing animals.

The drastic examples of fattening and killing animals in passage II, 1.997A, which demonstrate certain cruel practices aimed at improving the taste of their meat, serve Plutarch to present another issue he criticizes about eating animals:

${ }^{22}$ Helmbold in Loeb's edition does not follow the conjecture of Pohlenz, who adds the conjunction кai before ötı. It changes the meaning of the passage because the reading from the manuscript suggests that it was Xenocrates who told about this incident with the Athenians, setting the terminus ante quem of the incident in $396 \mathrm{BC}$, when Xenocrates died. In any case, the date of this incident is irrelevant for the topic of this article, so I leave Helmbold's version unchanged. 
From these practices it is perfectly evident that it is not for nourishment or need or necessity, but out of satiety and insolence and luxury that they have turned this lawless custom into a pleasure. [...] so intemperance in eating passes beyond the necessary ends of nature and resorts to cruelty and lawlessness to give variety to appetite. [...] Just so intemperate intercourse follows a lawless meal (II, 2.997A-C).

The objection is simple and returns to the beginning of the first speech of De esu carn.: it is not necessary for humans to feed on animals, but they still do that only for their pleasure. Plutarch uses a strongly negative term v̋ $\beta \rho \iota$, which in Greek has a broader meaning than just "insolence"; nota bene it was used once before to describe a man's attitude towards animals in a cited "forensic speech" from the passage I, 4.994E (translated as "arrogance”). So, because of this

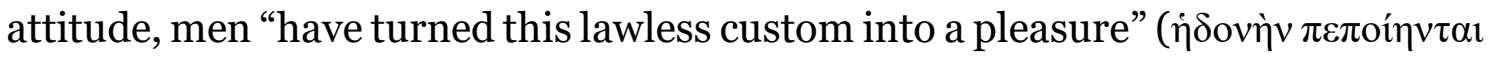

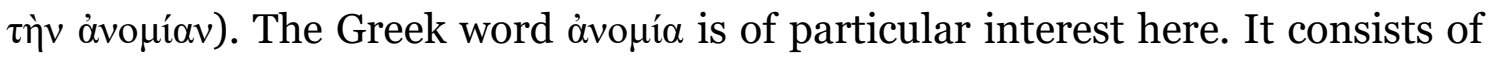
negating apha privativum and lexeme vó $\mu$ os, meaning "law". LSJ dictionary also

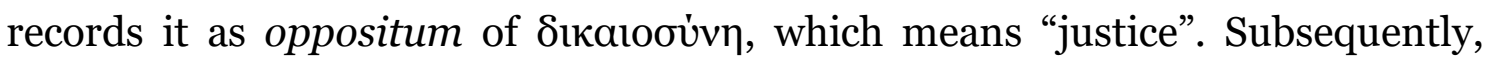

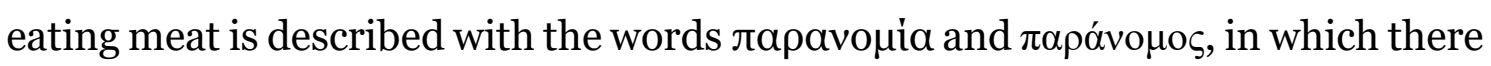
is a $\pi \alpha \rho \alpha ́$ preposition (“aside”, "beyond”, i.e., "amiss", "wrong”), used as a negating prefix instead of alpha privativum. So, in this short passage Plutarch three times refers to eating meat as to acting against justice or law, although in the previous chapter, at the beginning of second speech, there was his conditional permission to eat meat. However, conditional permission for something is not synonymous with justifying it - I will return to that question in my conclusion.

Since various thinkers joined the discussion on justice for animals through history, De esu carn. makes references several times to other philosophers who contributed to this discussion. Unsurprisingly, Pythagoras and Empedocles are referenced: "Pythagoras and Empedocles who try to accustom us to act justly toward other creatures also" (II, 3.997E). To be precise, Plutarch uses

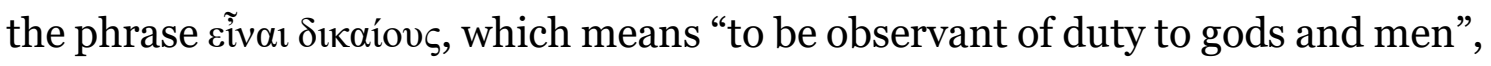
"righteous"; "lawful”, "just”. It is especially worth noting how he terms animals themselves in the sentence above and in the next quotation: "But apart from these considerations, do you not find here a wonderful means of training in social responsibility? Who could wrong a human being when he found himself so gently and humanely disposed toward other non-human creatures?” (I, 7.996A) 
Plutarch argues that vegetarianism and abstinence from killing animals is a good exercise for "humanity, benevolence and kind-heartedness" because these are the primary meanings of the Greek word $\varphi \imath \lambda \alpha v \theta \rho \omega \pi i \alpha$. He simply assumes that a man

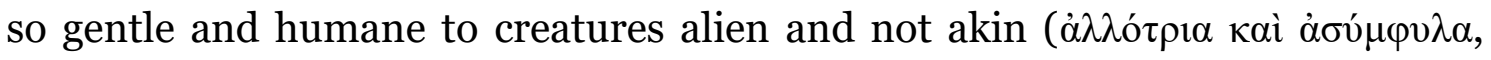
translated by Helmbold as "other non-human creatures") would not wrong another man, a creature of the same kind. Plutarch clearly underlines this "otherness" of animals and this is an element that distinguishes his attitude. His predecessors, especially those originating from the Pythagorean tradition, pointed rather to the kinship of animals and humans, sometimes even suggesting that they had the same soul (Guthrie, 1962, p. 186-187). But abstinence from killing animals because of the presence of human's soul in them still remains anthropocentric. The quotation above also includes anthropocentric argument because vegetarianism is presented as a means of improving men's attitude towards each other, as avoiding violence against weaker creatures is supposed to mould the same attitude towards equal creatures. However, it should be noticed that Plutarch intentionally considers animals beings other and different, and that he does not base his postulate of justice for animals on their supposed similarity to humans.

Before the text breaks off, the philosopher invokes the opinion of the Stoics, with whom he polemizes. Although speeches in De esu carn. are related to eating meat, a question about justice towards animals is also directly asked at the end:

"Of course", they say, "we human beings have no compact of justice with irrational animals". Nor, one might reply, have you with perfume or exotic sweetmeats either. Refrain from animals also, if you are expelling the useless and unnecessary element in pleasure from all its lurking-places.

Let us, however, now examine the point whether we really have no compact of justice with animals; and let us do so in no artificial or sophistical manner, but fixing our attention on our own emotions and conversing like human beings with ourselves and weighing... (II, 6-7.999A-B)

Twice here is used a sentence almost the same as in De soll. an., which expresses the position of the Stoics that there can be no concept of justice in relation to animals ("Therefore those who deny that there is any kind of justice 
owed to animals.", De soll. an. 14.970B). Plutarch opposes them by saying that they should refrain from animals as they refrain from perfume or sweetmeats, as well as from unnecessary and useless things. After all, one of Plutarch's main arguments is that eating meat is something unnecessary. In chapter seven he announces the discussion on the subject of justice proper. Assumedly, this discussion would not take place in accordance with the principles of rhetorical art, but in accordance with "fixing our attention on our own emotions and conversing like human beings with ourselves and weighing”. Unfortunately, the rest of the text is missing, so there is no actual discussion in De esu carn. aimed primarily at the topic of justice for animals. However, Plutarch appealed to emotions more than once regarding the eating of animals, which is closely related to the issue of justice. So in spite of the loss of part of the text, one can describe quite accurately Plutarch's understanding of justice toward animals.

\section{Conclusion}

Plutarch believed that justice should also apply to animals. He meant by that resigning from killing animals and giving them the right to life. He repeatedly refers to killing animals and eating meat as an offence against the law or even the nature. Nevertheless, in the interspecies justice there would be exceptions to the prohibition of killing. These exceptions would be allowed only by necessity. For instance, it would be permissible to kill dangerous and harmful animals in selfdefence. Killing animals for food may also be allowed, but only if a man is unable to feed himself with foods of vegetable origin and if this is his only way of survival. Plutarch also postulates just treatment of animals working with men. Of course, animals can be used for work especially because in Antiquity people could not do without the help of animals in many spheres of life, so the postulate of complete abandonment of their work would be unthinkable. However, the use of animals must be limited by certain rules. First of all, working animals cannot be overloaded, so using them cannot be harmful to them. Moreover, in exchange for their work, they should be cared for, even in their old age when they can no longer work. This is the ideal situation in the view of the philosopher of Chaeronea. However, Plutarch was aware of how difficult his ideal vision of justice between humans and animals is to achieve. Consequently, he simultaneously offers a 
softer version of his postulates. He at least urges people not to mistreat animals, since giving up their meat is impossible. He also calls for limiting meat consumption by arguing health reasons, but his intention possibly is to reduce the number of animals being killed.

The sources of such a friendly attitude of Plutarch to animals include both the vegetarianism of the Pythagorean and Orphic traditions, resulting from religious motives, and the approach to animals and their rationality presented by the Platonic Academy. These inspirations, merging in the person of Plutarch with his individual and benevolent nature, resulted in the creation of the theory of justice towards animals described in this paper.

Article received on 19.09.2018, accepted on 02.01.2019.

\section{BIBLIOGRAPHY}

\section{Primary Sources}

Aratus. Phaenomena. Callimachus. Hymns and Epigrams. Lycophron. Aratus. Translation by A.W. Mair \& G.R. Mair, 1921. Available online: <http://www.theoi.com/Text/AratusPhaenomena.html>. Acess: 11 fev. 2019.

Aristotle. Ethica Nicomachea. Edited by J. Bywater. Oxford: Clarendon Press, 1894. 1

. Politica. Edited by W.D. Ross. Oxford: Clarendon Press, 1957.

Chrysippus. De Anima Hominis. Stoicorum Veterum Fragmenta. Collegit Ioannes ab Arnim. Stutgardiae in Aedibus B. G. Teubneri, 1964, vol. 2.

Diogenes Laertios. Lives of Eminent Philosophers. Edited by R.D. Hicks. Cambridge: Harvard University Press, 1972.

Empedocles. Katharmoi. Die Fragmente der Vorsokratiker. Griechisch und Deutsch von Hermann Diels. Berlin: Weidmannsche Buchhandlung, 1906.

Euripides. Alcestis. Cyclops. Alcestis. Medea. Edited and translated by David Kovacs. Cambridge, MA/London: Harvard University Press, 2001.

. Hippolytus. Children of Heracles. Hippolytus. Andromache. Hecuba. Edited and translated by David Kovacs. Cambridge, MA/London: Harvard University Press, 1995.

Herodotus. Histories. Translation by A.D. Godley. Cambridge, MA/London: Harvard University Press/William Heinemann, 1960, vol. 1.

Hesiod. Works and Days. The Homeric Hymns and Homerica. Translation by Hugh G. Evelyn-White. Cambridge, MA/London: Harvard University Press/William Heinemann, 1959. 
Plato. Leges. Platonis Opera. Recognovit Brevique Adnotatione Critica Instruxit Ioannes Burnet. Oxford: Oxford Classical Texts, 1907, vol. 5.

Plutarch. Marcus Cato. In: Lives. Translation by Bernadotte Perrin. Cambridge, MA/London: Harvard University Press/William Heinemann, 1912, vol. 2.

. Moralia. Translation by Frank Cole Babbitt. Cambridge, MA/London: Harvard University Press/William Heinemann, 1928, vol. 2.

. Moralia. Translation by W.C. Helmbold. Cambridge, MA/London: Harvard University Press/William Heinemann, 1939, vol. 6.

Moralia. Translation by Harold Cherniss \& W.C. Helmbold. Cambridge, MA/London: Harvard University Press/William Heinemann, 1957, vol. 12.

Bernardakis. Lipsiae, 1891, vol. III.

Plutarchi Chaeronensis Moralia. Recognovit Gregorius N.

Plutarchi Chaeronensis Moralia. Recognovit Gregorius N. Bernardakis. Lipsiae, 1892, vol. IV.

Plutarchi Chaeronensis Moralia. Recognovit Gregorius N. Bernardakis. Lipsiae, 1895, vol. VI.

Porphyry. On Abstinence from Killing Animals. Translated by Gillian Clark. London/New York: Bloomsbury Academic, 2014

\section{Secondary Sources}

Balaudé, Jean-François. Parenté du vivant et végétarisme radical: Le «défi» d'Empédocle. In: Cassin, Barbara; Labarrière, Jean-Louis; Romeyer-Dherbey, Gilbert (eds) L'animal Dans l'Antiquité. Paris: Librairie Philosophique J. Vrin, 1997, p. 31-54.

Becchi, Francesco. Istinto e intelligenza negli scritti zoopsicologici di Plutarco. In: Bandini, Michele; Pericoli, Federico G. (eds) Scritti in Memoria di Dino Pieraccioni. Florence: Istituto Papirologico G. Vitelli, 1993, p. 59-83.

205-225.

Irrazionalità e razionalità degli animali. Prometheus, vol. 26, 2000, p.

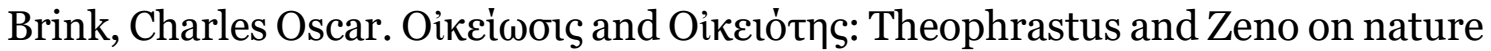
in moral theory. Phronesis, vol. 1, n. 2, 1956, p. 123-145.

Cornelli, Gabriele. In Search of Pythagoreanism: Pythagoreanism as an Historiographical Category. Berlin/Boston: De Gruyter, 2013.

Cornelli, Gabriele; McKirahan, Richard; Macris, Constantinos (eds) On Pythagoreanism. Berlin/Boston: De Gruyter, 2013.

Dierauer, Urs. Tier und Mensch im Denken der Antike: Studien zur Tierpsychologie, Anthropologie und Ethik. Amsterdam: B.R. Grüner, 1977.

Edwards, G. Fay. Irrational animals in Porphyry's logical works. A problem for the consus interpretation of On Abstinence. Phronesis, vol. 59, 2014, p. 22-43.

. The purpose of Porphyry's rational animals. A dialectical attack on the

Stoics in On Abstinence From Animal Food. In: Sorabji, Richard (ed.) Aristotle 
Re-Intepreted. New Findings On Seven Hundred Years Of The Ancient Commentators. London: Bloomsbury Academic, 2016, p. 263-290.

Guthrie, William Keith Chambers. A History of Greek Philosophy. Vol. 1, The Earlier Presocratics and the Pythagoreans. Cambridge: Cambridge University Press, 1962.

Haussleiter, Johannes. Der Vegetarismus in der Antike. Berlin: Verlag von Alfred Töpelmann, 1935.

Hubert Jr, Martin. Plutarch's De Sollertia Animalium 959 B-C: The discussion of the encomium of hunting. American Journal of Philology, vol. 100, n. 1, 1979, p. 99-106.

Krauss, Fritz. Die rhetorischen Schriften Plutarchs und ihre Stellung im Plutarchischen Schriftenkorpus. Nürnberg: Druck von J. L. Stich, 1912.

Lecky, William Edward Hartpole. History of European Morals: From Augustus to Charlemagne, Vol. 1. London: Longmans, Green, and Co., 1890.

Miszczyński, Damian. Wegetarianizm orfików i pitagorejczyków oraz jego możliwe przyczyny na podstawie wybranych źródet literackich. MA Thesis in Classical Philology. Kraków: Institute of Classical Philology, Jagiellonian University, 2015.

Newmyer, Stephen T. Plutarch on justice toward animals: Ancient insights on a modern debate. Scholia: Studies in Classical Antiquity, vol. 1, n. 1, 1992, p. 3854 .

Just beasts? Plutarch and modern science on the sense of fair play in animals. The Classical Outlook, vol. 74, n. 3, 1997, p. 85-88.

Animals, Rights and Reason in Plutarch and Modern Ethics, London/New York: Routledge, 2006.

. Animals in Greek and Roman Thought: A Sourcebook, London/New York: Routledge, 2011.

Rawls, John. A Theory of Justice. Cambridge, MA: The Belknap Press of Harvard University Press, 1999.

Roskam, Geert. Plutarch against Epicurus on affection for offspring: A reading of De amore prolis. In: Geert, Roskam; van der Stockt, Luc (eds) Virtues For The People: Aspects Of Plutarchan Ethics. Leuven: Leuven University Press, 2011, p. 175-202.

Sorabji, Richard. Animal Minds \& Human Morals: The Origins of the Western Debate, $1^{\text {st }}$ Edition 1993. London: Duckworth, 1995.

Steiner, Gary. Plutarch on the question of justice for animals. Ploutarchos, n.s., vol. 7, 2010, p. 73-82.

Tsekourakis, Damianos. Pythagoreanism or Platonism and ancient medicine? The reasons for vegetarianism in Plutarch's 'Moralia'. In: Haase, Wolfgang (ed.) Aufstieg und Niedergang der römischen Welt II.36.1. Berlin/New York: De Gruyter, 1987, p. 366-393.

West, Martin L. The East Face of Helicon: West Asiatic Elements in Greek Poetry and Myth, Oxford: Oxford University Press, 1997. 
Mare Nostrum, ano 2019, v. 10, n. 1

Ziegler, Konrat. Plutarchos von Chaironeia. Stuttgart: Alfred Druckenmüller Verlag, 1964. 